\title{
A REVIEW ON EXTRACTION PROCESSES OF LIGNOCELLULOSIC CHEMICALS FROM OIL PALM BIOMASS
}

\author{
NOORSHAMSIANA, A W*; NUR ELIYANTI, A O*; FATIHA, I* and ASTIMAR, A A*
}

\begin{abstract}
Oil palm biomass $(O P B)$ is a by-product derived from the oil palm industry; periodically available in the field during the replanting and pruning activities; and from the milling processes of palm oil. The biomass includes oil palm trunk (OPT), oil palm frond (OPF), kernel shell, oil palm empty fruit bunch (OPEFB), oil palm mesocarp fibre (OPMF), and palm oil mill effluent (POME). OPB is classified as lignocellulosic residues that typically contain cellulose, hemicellulose, and lignin in their cell wall that can be converted into fine chemicals. These lignocellulosic chemicals have significant potential applications in food, chemicals and pharmaceuticals industries. A number of different types of extraction technologies have been developed; namely chemicals, physico-chemicals, biochemicals or the combinations of these processes. But as the methods that are environmental-friendly are the current trend, this article has its focus entirely on green technologies. This article comprehensively reviews the conversion of OPB into lignocellulosic chemicals with special attention on various extraction processes, followed by discussion on their special merits as well as their weaknesses. Sustainability for each of the process is also considered in detail in the discussion.
\end{abstract}

Keywords: oil palm biomass, lignocellulosic chemicals, cellulose, extraction process.

Date received: 11 October 2017; Sent for revision: 12 October 2017; Received in final form: 24 November 2017; Accepted: 6 December 2017.

\section{INTRODUCTION}

Malaysia has established its name as a large producer and exporter of palm oil in the world, second only to Indonesia. The oil palm industry in Malaysia, spanning 5.74 million hectares of plantation and 453 palm oil mills, produced over 17.32 million tonnes of oil and almost 100 million tonnes of biomass (MPOB, 2016). Oil palm biomass (OPB) is a by-product derived from the oil palm industry; periodically available in the field during the replanting and pruning activities; and from the milling processes in the palm oil mills. The biomass includes oil palm trunk (OPT), oil palm frond (OPF),

Malaysian Palm Oil Board,

6 Persiaran Institusi, Bandar Baru Bangi,

43000 Kajang, Selangor, Malaysia.

E-mail: noorsham@mpob.gov.my kernel shell, oil palm empty fruit bunch (OPEFB), oil palm mesocarp fibre (OPMF) as well as palm oil mill effluent (POME) comprising of sludge water as well as some solids made up of debris from palm fruit mesocarp. Based on the formula used in the estimation of oil palm biomass extractable per hectare of plantation (Astimar et al., 2011), in the year 2016, from 84769 ha of replanting about 6.32 million tonnes (dry weight) of OPT were felled for replanting and 61.20 million tonnes (dry weight) of OPF were also produced during pruning and replanting from the plantation. In 2016, 453 palm oil mills in Malaysia processed 85.84 million tonnes of fresh fruit bunches (FFB) generating approximately 6.61 million tonnes (dry weight) of OPEFB, 6.95 million tonnes (dry weight) of OPMF and 4.01 million tonnes (dry weight) of kernel shell. An abundant quantity of biomass generation in the oil palm industry provides huge resources for the 
conversion into value-added products, as the OPB is inexhaustible, renewable, biodegradable, recyclable and a derivatisable biopolymer.

The depletion of fossil fuels and natural raw materials has encouraged the search for the development of new resource materials for the production of bio-based materials (Alekhina et al., 2014). OPB is classified as lignocellulosic residues that mainly comprise of cellulose, hemicellulose, and lignin in their cell wall (Raveendran et al., 1995). This lignocellulosic material can be converted into a valuable feedstock for the production of biosugar, biocompost, biochemical and bioethanol. Due to lignocellulosic nature of OPB, countless research and development activities are undertaken by various agencies in order to improve the transformation of OPB into more valuable substrate for producing a variety of chemicals that will have huge potential in food, chemicals and pharmaceuticals industries.

The chemical constituents in OPB are varied considerably due to their diverse origins and types (Chew and Bhatia, 2008). The chemical composition of different OPB is shown in Table 1.

Cellulose forms a major constituent of most OPB. Only cellulose and hemicellulose can be converted to fermentable sugars. These lignocellulosic chemicals are reinforced in a lignin matrix similar to that of other natural fibres. Recovery of these components from the OPB requires some kind of pre-treatment. The pathway of different pre-treatments on OPB to extract lignocellulosic chemicals and production of fermentable sugars is as shown in Figure 1.

A pre-treatment method is intended to remove lignin, reduce crystallinity of the cellulose and increase the porosity of lignocellulosic materials in order to make cellulose and hemicellulose more amenable to the hydrolysis and fermentation processes that are used to convert these lignocellulosic chemicals to fermentable sugars in higher yield (Balat, 2011; Mora-Pale et al., 2011; Moiser et al., 2005). Various pre-treatment methods have been developed to extract these lignocellulosic chemicals. These include physical pre-treatments (e.g. size reduction, steaming, hot water, steam explosion) chemicals methods (e.g. acid, alkali, organic solvents), biological treatments (enzyme and microbes) and their combination. Furthermore, interest in green extraction has been revived by the increasing public concern towards the environment. The extraction of lignocellulosic chemicals using less solvent at low concentration, less toxic and non-toxic chemicals in combination with physical treatments that are less energy intensive are considered as green methods (Rabemanolontsoa and Saka, 2016; Marzialetti et al., 2011; Nazir et al., 2013; 2012; Kumar et al., 2009; Quesada et al., 1999). Among aforementioned pre-treatment options, chemical treatment and its combination have been the most reported method for the lignocellulosic conversion into chemicals (Kumar and Sharma, 2017; Sun et al., 2016; Kim et al., 2016; Brodeur et al., 2011).

By recovering all the lignocellulosic chemicals in the OPB, it will not only be able to solve the disposal problem, but it can create value-added products from these oil palm industry by-products (Mohd Nasir and Saleh, 2016; Mohtar et al., 2015; Medina et al., 2015; Yonga et al., 2016; Norzita and Lani, 2014; Zakaria et al., 2014a; Nazir et al., 2013; Amin et al., 2010; Robiah et al., 2010; Rosnah et al., 2006; 2009; Astimar et al., 2002). This review article reviews exclusively on all techniques that have been developed and used for the conversion of OPB into lignocellulosic chemicals with a focus on various extraction processes, and discussion on their advantages and disadvantages. Insights on the sustainability of each of the process are also included in the discussion.

\section{CHEMICAL PRE-TREATMENT}

Chemical pre-treatment is one of the most promising methods to extract the lignocellulosic chemicals from biomass. It has been extensively used for

TABLE 1. CHEMICAL CONTENT IN COMMON OIL PALM BIOMASS FEEDSTOCKS

\begin{tabular}{|c|c|c|c|c|c|}
\hline \multirow{2}{*}{ Composition } & \multicolumn{5}{|c|}{ Oil palm biomass chemical composition (wt \%) } \\
\hline & EFB & OPF & OPT & OPMF & Kernel shell \\
\hline Cellulose & $38-70$ & $40-50$ & $22-44$ & $39-42$ & $13-28$ \\
\hline Hemicellulose & $10-35$ & $23-38$ & $12-41$ & $9-24$ & $21-22$ \\
\hline Holocellulose & $68-86$ & $70-83$ & $42-73$ & $49-64$ & $42-47$ \\
\hline Lignin & $13-37$ & $18-32$ & $18-36$ & $21-33$ & $44-52$ \\
\hline Xylose & $29-63$ & $26-52$ & $15-55$ & $40-49$ & $63-64$ \\
\hline Glucose & $23-66$ & $20-67$ & $18-32$ & $23-29$ & $21-22$ \\
\hline Ash & $1-6$ & $2-8$ & $2-4$ & 3-9 & $1-2$ \\
\hline
\end{tabular}

Note: EFB - empty fruit bunch. OPF - oil palm frond. OPT - oil palm trunk. OPMF - oil palm mesocarp fibre.

Source: Mohtar et al. (2015); Ching and Ng (2014); Rugayah et al. (2014); Mohd Basyaruddin et al. (2012); Shinoj et al. (2011); Bono et al. (2009); Chew and Bhatia (2008); Saka et al. (2008); Shibata et al. (2008); Abdul Khalil et al. (2006, 2008); Law et al. (2007); Wan Rosli et al. (2007); Abdul Khalil and Rozman (2004); Law and Jiang (2001); Sreekala et al. (2001); Kirkaldy and Susanto (1976). 


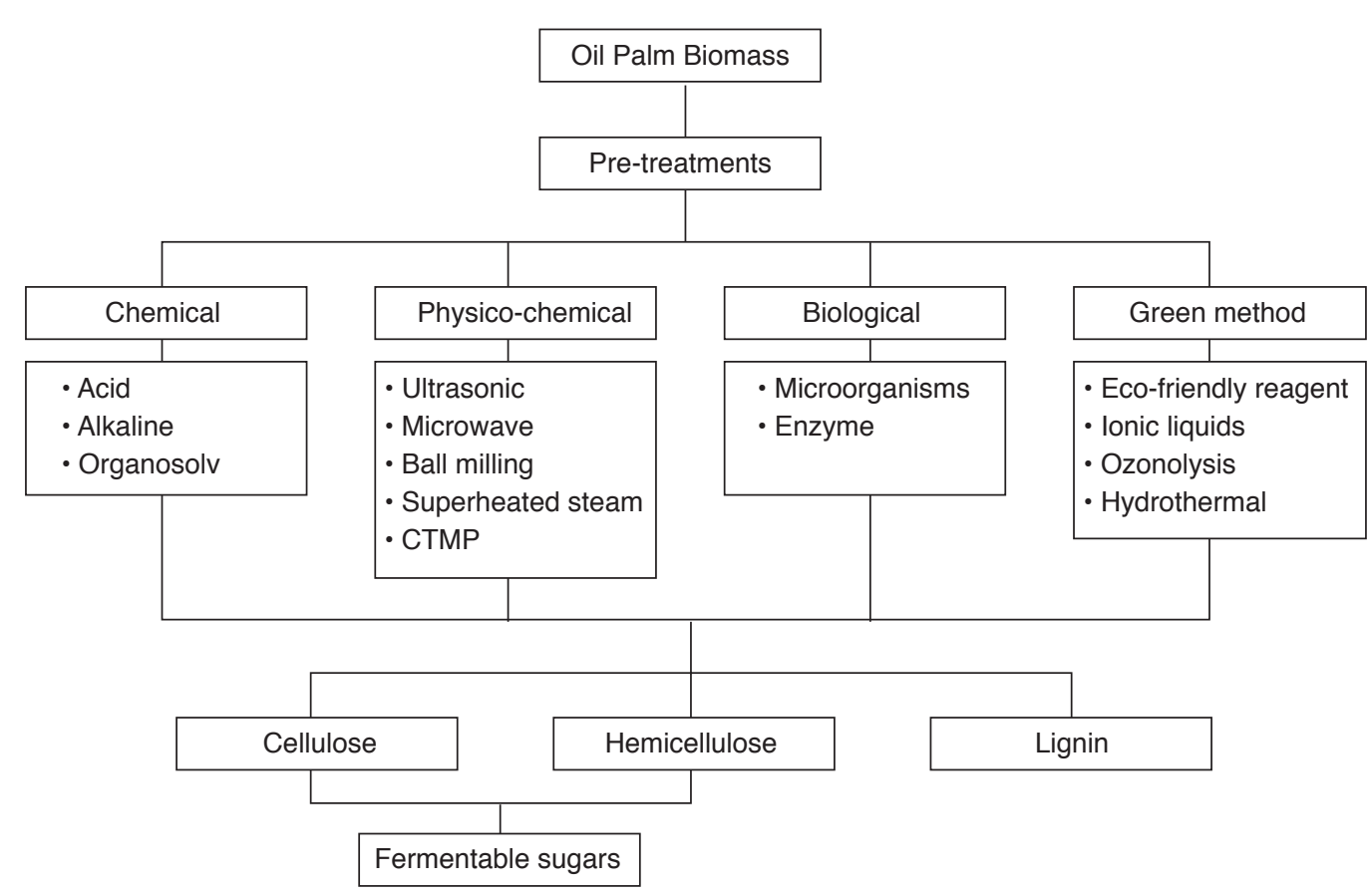

Figure 1. Pathway of different pre-treatments on oil palm biomass (OPB).

cellulosic extraction in the pulp and paper industry (Zheng et al., 2009). This method also has been exploited to enhance the yield of lignocellulosic chemicals. Furthermore, there are chemicals that have been reported to have a significant effect on the structure of lignocellulosic biomass, where the pretreatments can be carried out at room temperature and pressure but they do not produce toxic residues for the downstream processes. The chemicals used in chemical pre-treatment are selected from oxidising agents, alkali, acids and salts that are purely initiated by the chemical reactions for breaking biomass structure to degrade and / or extract lignin, hemicelluloses and cellulose.

\section{Acid Pre-treatment}

Acids are very effective and widely known chemical that have access to glucosidic bonds in hemicellulose and cellulose in biomass. Acids have the ability to remove hemicellulose and they have been used as parts of overall processes in fractionating the components of lignocellulosic biomass (Zhang et al., 2007). The pre-treatment using acid requires high temperature and pressure to achieve high yield of the targeted chemicals. The reaction also depends on several parameters like type of acid, concentration of acid and ratio of solid to liquid.

Different kinds of acid have been used such as sulphuric acid, nitric acid, hydrochloric acid and phosphoric acid. A number of studies have investigated the pre-treatment using sulphuric acid due to its high catabolic activity. Dilute sulphuric acid has traditionally been used to manufacture furfural from biomass (Esteghlalian et al., 1997). This chemical pre-treatment usually involves the addition of diluted acids (range from $0.1 \%$ to $2.5 \% \mathrm{w} / \mathrm{w})$ to the biomass, followed by reaction temperatures between $130^{\circ} \mathrm{C}$ and $210^{\circ} \mathrm{C}$ (Nguyen et al., 2000; Saha et al., 2005).

Kristiani et al. (2013) reported that the pretreatment in $0.25 \%-2 \%$ of $\mathrm{H}_{2} \mathrm{SO}_{4}$ did increase the specific surface area of cellulose from 2.23 to 5.57 $\mathrm{m}^{2} \mathrm{~g}^{-1}$, and also showed the decreasing crystallinity of cellulose. Other studies done by Amirkhani et al. (2015) showed that $94 \%$ conversion of xylose was obtained under $2 \%$ of $\mathrm{H}_{2} \mathrm{SO}_{4}$ at $120^{\circ} \mathrm{C}$ and $20 \mathrm{~min}$ of reaction times. Lignin preparation from OPEFB by successive treatment with $1 \%(\mathrm{w} / \mathrm{w}) \mathrm{H}_{2} \mathrm{SO}_{4}$ at $121^{\circ} \mathrm{C}$ for $60 \mathrm{~min}$ and followed by treating in $2.5 \% \mathrm{NaOH}$ at $121^{\circ} \mathrm{C}$ for $80 \mathrm{~min}$ resulting in a high lignin yield of 28.89\% (Medina et al., 2015).

The disadvantage of this method is the high operational and maintenance cost compared to other chemical pre-treatment (e.g., dilute alkali) and physico-chemical methods [e.g., steam explosion and ammonia fibre explosion (AFEX)] (Sun and Cheng, 2002; Kumar and Murthy, 2011). A suitable material for the reactor is required to withstand the corrosiveness and toxicity of the acid. An extensive washing and / or a detoxification step is also required to remove the acid before further step is taken for other product (Nguyen et al., 2000; Saha et al., 2005; Sassner et al., 2008).

Acid pre-treatment also allows to further hydrolyse the hemicelluloses, especially xylan into sugar such as xylose, mannose, acetic acid, 
galactose, glucose, etc. In an industrial process, the reaction is always at high temperatures and pressures that lead to the degradation of glucose and xylose into furfural and hydroxymethyl furfural (HMF), respectively and also other further degradation forms such as formic acid and levulinic acid (Kootstra et al., 2009; Davies et al., 2011). Partial breakdown of lignin also leads to the formation of the phenolic compounds.

Organic acids such as maleic, oxalic, succinic, fumaric and acetic acid have been suggested as an alternative due to their relatively low acidities and high solubility to lignin. Yonga et al. (2016) obtained the highest yield of furfural (35.8\%) after treating OPF in formic acid at high temperatures $\left(240^{\circ} \mathrm{C}-280^{\circ} \mathrm{C}\right)$. The advantage of using organic acid is the monocarboxylic acid has lower catalytic performance due to their difference in $\mathrm{pKa}$ compared to dicarboxylic acids (Trzcinski and Stuckey, 2015).

\section{Alkaline Pre-treatment}

Alkali compound or salt or catalyst is widely studied in chemical pre-treatment. Various alkali reagents have been used such as sodium hydroxide (Silverstein et al., 2007; Wang et al., 2010), potassium hydroxide (Wanitwattanarumlug et al., 2012; Sharma et al., 2013), calcium hydroxide (lime) (Sierra et al., 2009), ammonium hydroxide (Prior and Day, 2008; Sherman et al., 2012), aqueous ammonia (Kim et al., 2009) and hydrogen peroxide or combination of these (Banerjee et al., 2012). Alkaline hydrolysis can be operated at lower temperature and pressure compared to other chemical pre-treatment method, but the reaction times can differ depending on the different types of biomass used (Bali et al., 2015). During the alkaline hydrolysis process, the structure of biomass is swelling, leading to alteration of lignin structure and breaking the ester and glycosidic chains.

Pre-treatment of OPF with aqueous $\mathrm{NaOH}$ $(4.42 \%)$ at $100^{\circ} \mathrm{C}$ for $58.31 \mathrm{~min}$ resulted in better separation of cellulose, hemicellulose and lignin, which were $41.42 \%, 31.93 \%$ and $26.06 \%$, respectively (Mohd Sukri et al., 2014). $\mathrm{KOH}$ has selectively removed xylan (Hendriks and Zeeman, 2009). Mohd Nasir and Saleh (2016) reported that they have extracted xylan from EFB in $3 \mathrm{M} \mathrm{KOH}$ at $40^{\circ} \mathrm{C}$, with $4 \mathrm{hr}$ of extraction time. A technology on xylooligosaccharides $(\mathrm{XO})$ production from OPEFB-xylan using immobilised xylanase in a packed bed column reactor has been developed by Noorshamsiana et al. (2015). The OPEFB was pre-treated with $\mathrm{KOH}$ and the resulting xyian was further hydrolysed for $\mathrm{XO}$ generation.

The significant disadvantage is that the alkali salt was found to be converted into irrecoverable salts that may be absorbed by the biomass during the pre-treatment process. The presence of a large amount of salt is a challenging issue for alkaline hydrolysis (Zheng et al., 2009). This method can be improved by the addition of other chemicals such as urea (Zhao et al., 2008) or in combination with other pre-treatment methods. Acid pre-treatment (removal of hemicellulose) followed by alkali pretreatment (removal of lignin) results in a relatively pure cellulose.

\section{Organosolv Pre-treatment}

The organosolvation pre-treatment method has drawn a lot of attention since it has the potential for utilisation in lignocellulosic chemicals. In organosolv pre-treatment, organic solvents are used to extract lignocellulosic chemicals, where the solvent will increase the pore of the biomass and enhances accessibility to the surface area of lignocellulosic biomass and significantly reduce the lignin contents (Zhao et al., 2009). Organosolv pretreatment usually operate at a range of $150^{\circ} \mathrm{C}-200^{\circ} \mathrm{C}$. The most common solvent used in the pre-treatment process are ethanol, methanol, acetone, glycerol, aqueous phenol,ethylene glycol, triethylene glycol, aqueous n-butanol, tetrahydrofurfuryl alcohol, etc. (Taherzadeh and Karimi, 2008).

Ethanol is the most preferred solvent in industries due to its lower cost and low boiling point compared to other alcohols such as ethylene glycol, tetrahydrofurfuryl alcohol, etc (Arato et al., 2005). Ethanol also has low toxicity and easy to recover. Ethanosolv has been explored as an alternative to kraft pulping (Pye and Lora, 1991). Goh et al. (2011) have used aqueous ethanol [64\% (w/w)] at $160^{\circ} \mathrm{C}-200^{\circ} \mathrm{C}$ for $45-90 \mathrm{~min}$ and obtained $96.3 \%$ recovery of glucose. Alroils et al. (2009) reported that they have used $80 \%$ of ethylene glycol in order to separate the cellulose, hemicellulose and lignin from OPEFB.

Through the organosolv process, the cost can be reduced by recycling the solvents from the process, but still there are potential hazards in handling such large volumes of organic solvents that limits the utilisation of pretreatment process.

\section{PHYSICO-CHEMICAL PRE-TREATMENT}

The physico-chemical processes are the improvements of existing chemical processes, to reduce reaction time and improve the efficiency of the process. In order to enhance the removal of lignin and increase their efficiency, physical parameters such as pressure and temperature are added to the established chemical pre-treatment. In previous studies, various types of physico-chemical pretreatments for oil palm lignocellulosic biomass were used. These included pre-treatments such as ultrasonic, microwave, ball milling, superheated 
and chemical thermo-mechanical. A brief description of these technologies is given below.

\section{Ultrasonic Pre-treatment}

Ultrasonic pre-treatment is relatively new in lignocellulosic biomass pre-treatment technology. The effect of ultrasound on lignocellulosic biomass is to enhance the extractability of hemicelluloses, cellulose or lignin component. It is also used to clean cellulosic fibre from used paper and to improve the susceptibility of lignocellulosic materials to biodegradation by using ultrasound power (Asakura et al., 2008). Besides that, it can generate a pre-treated substrate to be more easily hydrolysed via increasing the accessible surface area and influencing the crystallinity (Toma et al., 2007). In order to determine the optimal conditions of ultrasonic exposure for the pretreatment of lignocellulosic biomass, the efficiency of acid hydrolysis has been evaluated. Previous research done by Robiah et al. (2010) have found that a maximum xylose yield of $58 \%$ was achieved when the OPEFB fibre was ultrasonicated at $90 \%$ amplitude for $45 \mathrm{~min}$. The hydrolysis occurred at a low temperature using $2 \%$ sulphuric acid; $1: 25$ solid-liquid ratio and $100^{\circ} \mathrm{C}$ operating temperature.

\section{Microwave Pre-treatment}

The combined microwave-chemical pretreatment of different feedstock resulted to higher sugar recovery. Several chemicals were used in microwave/chemical pre-treatment such as microwave-assisted dilute ammonia (Chen et al., 2012) and microwave-assisted $\mathrm{FeCl}_{3}$ (Lu and Zhou, 2011). Recently, there are two most commonly studied chemical methods in the pre-treatment of lignocellulosic biomass which are the microwave assisted-alkaline and microwave-assisted acid pre-treatments. In previous research done by Komolwanich et al. (2014), pre-treatment on OPEFB was done using the combination of microwave and $\mathrm{NaOH}$. It is found that the enzymatic saccharification of OPEFB was significantly improved by the removal of more lignin and hemicellulose and enhancing the cellulose accessibility during the pre-treatment. Researchers indicate that microwave drying with proper selection of power input, weight of drying material and drying time could increase the drying rate. As a result, it could save up to $50 \%$ of energy and significantly decrease the volatile organic compound emissions when compared with the conventional drying methods (Guanben et al., 2005). In fact, microwaves can dry wood strands under lower temperatures and higher rates to produce dried wood with uniform and less moisture content and more permeability (Nomanbhay et al., 2013; Torgovnikov and Vinden, 2002; Vermaas, 1995).
It should suffer from less shrinkage and swelling, as compared to that produced by kiln drying and traditional methods which are much more time consuming and less cost-effective (Guanben et al., 2005; Leiker and Adamska, 2004; Zhang et al., 1997). It can be concluded that although the microwave energy consumption is relatively higher than that of oven drying based on watt $/ \mathrm{hr}^{-1}$, it can be considered that much lower time will make the total energy consumed to be significantly lower than that of conventional methods (Ethaib et al., 2015). Research done by Parisa et al. (2010) showed the effectiveness of microwave drying in reducing the time and better removal of moisture as compared to that of oven drying. They were able to get the optimum conditions at $6.89 \mathrm{~min}$ with a microwave power for a $1000 \mathrm{~g}$ sample and with $14.62 \%$ of moisture content.

\section{Ball Milling Pre-treatment}

Ball milling is one of the most commonly used mechanical activation processes to increase the surface area of lignocellulosic biomass. Particle sizes and crystallinity index values of the OPB were significantly reduced with extended ball mill processing time. When OPF fibre was pre-treated through ball mill, it produced glucose and xylose yields of $87 \%$ and $81.6 \%$, respectively, while OPEFB produced glucose and xylose yields of $70 \%$ and $82.3 \%$, respectively (Zakaria et al., 2014a). This makes milling a good choice as a preliminary pre-treatment method for a wide variety of lignocellulosic feedstocks.

\section{Superheated Steam Pre-treatment}

Superheated steam (SHS) can be an alternative treatment method for lignocellulose. SHS treatment is advantageous compared to steam explosion as it is conducted at atmospheric pressure. Currently, SHS has been mainly used for drying (Schwartze and Brocker, 2002; Hasibuan and Wan Daud, 2009). Previous work on the use of SHS for treating $\mathrm{OPB}$ in order to ease the enzymatic hydrolysis of the lignocellulose for sugar production has been reported (Nik Mahmud et al., 2013; Bahrin et al., 2012). These studies were done to reveal the potential of SHS as a novel and alternative treatment method for modification of lignocellulose towards biocomposite production. The treated OPMF obtained in these studies was analysed for its chemical component, thermal stability, chemical structure and morphological characteristic. Bahrin et al. (2012) have claimed that their research on SHS treatment of OPEFB for fermentable sugars production is the first to be reported.

Overall, the results obtained suggested that SHS is an effective treatment method for surface modification and subsequently improving the 
characteristics of the natural fibre. Most importantly, the use of novel, eco-friendly SHS may contribute to the green and sustainable treatment for surface modification of natural fibre (Ahamad Nordin et al., 2013).

\section{Chemical Thermal Mechanical Pre-treatment (CTMP)}

There are various methods of treatments that can be used for the removal of silica bodies from the surface of OPEFB fibres; heat treatment, chemical treatment and mechanical treatment. Robiah et al. (2010) treated the OPEFB fibres by using a combination of heat and chemical treatment; acid hydrolysis at $100^{\circ} \mathrm{C}$ and ultrasonic pre-treatment. On the other hand, Rosman et al. (2013) treated the OPEFB using alkali followed by silane treatment and found that the surface treatment of OPEFB fibres increases the compactibility with the matrix, thus producing superior mechanical properties of the reinforced polymer composite. The modifications of OPEFB fibres treated with sodium hydroxide and succinic acid increased the availability of functional groups through chemical modification, and interacted strongly with the matrix polymer to get better interfacial bonding between fibres and matrix (Bhat et al., 2011). Zawawi et al. (2015) reported that the effects of pre-treatments on the surfaces of EFB fibres are subjected to thermomechanical pulping (TMP) process. For fibres treated with $\mathrm{NaOH}$, the SEM images showed that alkali treatment made the fibre surface rougher with less amount of silica bodies. Most of the lignin and small amount of silica bodies were removed resulting in a rough surface. A study done by Ariffin et al. (2008) claimed that the combination of physical, chemical and thermal pretreatments have successfully altered the physical structure and chemical composition of the OPEFB, as well as in reducing sugar production. OPEFB treated by chemical treatment followed by thermal is the best treatment in order to produce the reducing sugars as compared to the reversed pre-treatment technique.

\section{BIOLOGICAL PRE-TREATMENTS}

In comparison with the conventional chemical and physico-chemical pre-treatment methods, biological pre-treatment is considered as an efficient, environmentally safe method as it has no requirement for chemicals and needs only mild environmental conditions employed as well as low-energy process. Substrate specificity and simple process and equipment requirements are other advantages that have been reported (Kirk and Chang, 1981). Biological pre-treatments are carried out by microorganisms such as brown-rot fungi, white and soft-rot fungi as well as bacteria, and their enzymes system, which mainly degrade lignin and hemicellulose and a little amount of cellulose (Vats et al., 2013; Ray et al., 2010; Hamisan et al. 2009; Kurakake et al., 2007; Taniguchi et al., 2005; Hataka, 1983). Recently, this environmentalfriendly approach has received renewed attention as a pre-treatment technique for enhancing enzymatic hydrolysis for various lignocellulosic biomass. However, literature review has indicated that limited studies have been conducted on biological treatment of OPB.

\section{Microorganisms Pre-treatment}

The most intensively investigated microorganisms in the biological pre-treatment of lignocellulosic biomass are the white fungi as their ligninolytic enzyme could degrade lignin efficiently (Isroi et al., 2011; Tanaguchi et al., 2005; Zadražil and Puniya, 1995; Martinez et al., 1994). Microbial pre-treatment using Phanerochaete chrysosporium ATTCC 32629, showed significant lignin removal from OPEFB with an optimum value of 5.89 Klason lignin. Nevertheless, for the same value of Klason lignin, delignification by chemical pre-treatment needs only $3 \mathrm{hr}$ as compared to seven days for microbial pre-treatment. It is also reported that the lignin removal is dependent on the microbial ability, either to consume lignin or to produce biological products such as enzymes, to remove lignin (Hamisan et al., 2009). Isroi et al. (2012) studied a single biological pre-treatment and a combination of phosphoric acid and biological treatment on OPEFB. Biological pre-treatment was carried out using the white-rot fungus Pleurotus floridanus. The composition of OPEFB was slightly changed by the fungal pre-treatment, but it was significantly altered by the fungal followed by phosphoric acid pre-treatment. The fungal pre-treatment resulted in the least losses of both total solid $(1.31 \%)$ and total carbohydrates $(7.89 \%)$ compared to the combined pre-treatment of fungal followed by phosphoric acid; the losses of total solid and total carbohydrates were correspondingly $63.55 \%$ and $33.77 \%$. Thus, using fungal pre-treatment, much more lignocellulosic material remains to be utilised, and it has less environmental impacts.

\section{Enzymatic Pre-treatment}

Generally, enzymatic pre-treatment is given to the lignocellulosic biomass prior to the subsequent process for lignin degradation, hence cellulose will become more accessible. Amin et al. (2010) studied the effect of enzymatic pre-treatment on OPEFB prior to the pyrolysis process for degrading the lignin structures. The percentage lignin degraded 
by lignin peroxidase (LiP) enzyme and manganese peroxidase $(\mathrm{MnP})$ enzyme were recorded at $71.69 \%$ and $67.94 \%$, respectively. The enzymatic treated OPEFB have resulted in higher bio-oil yield (30 $\mathrm{wt} \%$ ) compared to the untreated sample (20 $\mathrm{wt} \%$ ). Nazlee et al. (2017) reported that it is possible to produce sugars from the cellulose of OPEFB fibre by enzymatic hydrolysis in membrane reactor. The cellulolytic complex enzyme commercially known as Celluclast 1.5L (Novozymes) when employed was able to increase productivity from 0.003 to 0.01 $\mathrm{g}$ reducing sugars/FPU enzyme in batch reactor and enzymatic reactor. The reusability of cellulose enzyme was also reported up to $216 \mathrm{hr}$ in enzymatic membrane reactor.

\section{GREEN PRE-TREATMENT}

A technology that reduces or eliminates the hazardous chemicals used as well as an application of safer solvent and safer reaction conditions would qualify it as a green treatment. The use of green technology to recover lignocellulosic chemicals from the OPB is to reduce environmental impact. The extraction of lignocellulosic chemicals using processes that employ less solvent at low concentration, less toxic and non-toxic feedstock selections in combination with physical treatments that are less energy intensive, are considered as green methods. In addition, ionic liquid, ozonolysis and hydrothermal pre-treatments also can be categorised as green methods as these methods eliminate the chemical usage.

\section{Eco-friendly Reagents}

Organic acids such as acetic acid and formic acid are eco-friendly reagents, less corrosive and effective for the pre-treatment of lignocellulosic biomass, and they provide a more stable medium for monosaccharide in the aqueous phase as compared to sulphuric acid (Marzialetti et al., 2011). The application of low concentrations of $20 \%$ (v/v) formic acid and 10\% (v/v) of 30\% hydrogen peroxide at $85^{\circ} \mathrm{C}$ for the extraction of cellulose from OPEFB produced a total cellulose yield of $64 \%$ $(\mathrm{w} / \mathrm{w})$, which was among the highest ever reported (Nazir et al., 2013). The extraction of cellulose fibres from OPEFB by hydrogen peroxide with an ultrasound-assisted alkali extraction yields $49 \%$ of cellulose (Nazir et al., 2012). The utilisation of eco-friendly reagents as an alternative to acidified sodium chlorite for the delignification and the extraction of cellulose from OPEFB will reduce the environmental impacts of hazardous chemicals. Besides that, low concentration of chemicals is being used resulting in low operating cost and this also is one of the advantages associated with this treatment.

\section{Ionic Liquids}

Ionic liquids are new organic salts, which generally exist in a liquid state at ambient temperature due to their low melting points. Principally, useful characteristics such as high ionic conductivity, high solvation power, thermal stability, inflammability, low volatility confer the status 'green solvent' on ionic acid for various chemical reactions in industrial processes (Rabemanolontsoa and Saka, 2016; Zhu et al., 2006; Heinze et al., 2005).

The development of a novel process that uses ionic liquid \{1-butyl-3methylimidazolium chloride $[(\mathrm{Bmim}) \mathrm{Cl}]\}$ followed by alkaline treatment to extract cellulose from OPEFB fibre with 93\% $\alpha$-cellulose recovery has been reported (Norzita and Lani, 2014). The improvement in the properties of cellulose obtained was observed to be $63 \%$ crystallinity with thermal decomposition step occurred at $390^{\circ} \mathrm{C}$. Thus, this process represents an efficient treatment in extracting cellulose with better properties and having the highest yield. In another study, the same types of ionic liquid; $(\mathrm{Bmim}) \mathrm{Cl}$ employed in the liquefaction process with sulphuric acid as a catalyst, managed to extract $26.6 \%$ lignin from EFB. The utilisation of recycled ionic liquid in the process showed no significant reduction of lignin yield (Sidek et al., 2013). Tan et al. (2011) studied the optimisation of glucose recovery from OPF by subjecting the OPF into ionic liquid $(\mathrm{Bmim}) \mathrm{Cl}$ prior to cellulose regeneration by an antisolvent. An optimum 100\% glucose recovery was obtained with pre-treatment conditions of $80^{\circ} \mathrm{C}$, a 15 min retention time and $10 \%$ solid loading by employing a response surface methodology. Mohd Basyaruddin et al. (2012) investigated the application of two different ionic liquids; namely 1-butyl-3-methylimidazolium chloride/dimethyl sulphoxide and 1-ethyl-3-methylimidazolium chloride/dimethyl sulphoxide on the swelling and dissolution of OPB and cellulose fibre from OPEFB, OPF and OPT. These OPB fibres treated with ionic liquids showed homogeneous swelling without dissolution, whereas the cellulose fibre from these OPB has been attributed to the subsequent swelling and dissolution mechanisms of the fibre when subjected to the ionic liquids. Lignin extraction from $\mathrm{OPB}$, namely OPEFB, OPT and OPF by dissolution in ionic liquid; 1-butyl-3-methylimidazolium chloride ([bmim][Cl]) followed by precipitation in various precipitating agent was reported by Mohtar et al. (2015). The lignin from these OPB was successfully extracted by ionic liquid dissolution and non-toxic $\mathrm{CO}_{2}$ - aluminum potassium sulphate dodecahydrate $\left[\left(\mathrm{AlK}\left(\mathrm{SO}_{4}\right)_{2} \cdot 12 \mathrm{H}_{2} \mathrm{O}\right]\right.$ precipitation process with the highest lignin yield was observed for OPT.

Ionic liquids can be claimed to be potential solvents in dissolving cellulosic materials, and have high potential as one of the green routes towards 
volatile organic solvent replacement. Regardless of their promising chemical properties, ionic liquids present the drawback of being expensive and require tedious recycling and reuse, since their toxicity and biodegradability are not well understood (Kumar and Sharma, 2017; Rabemanolontsoa and Saka, 2016).

\section{Ozonolysis}

Ozonolysis is an ozone treatment which is mainly used for reducing the lignin content of lignocellulosic biomass as it mainly degrades lignin, but negligibly affects hemicellulose and cellulose. The use of ozone treatment can be classified as a greener technology as this process produces no toxic residues and it is performed at ambient temperature and pressure (Kumar et al., 2009). Also, it does not produce any toxic inhibitors, therefore it is environment-friendly and does not affect the post-treatment process such as enzymatic hydrolysis and yeast fermentations (Quesada et al., 1999). This technique degrades most of the lignin and some of the hemicellulose, while leaving the cellulose intact. Some researchers conducted their research in this eco-friendly method with wheat straw (Ben and Miron, 1981), bagasse, green hay, peanut, pine (Neely, 1984) and poplar sawdust (Vidal and Molinier, 1988). However, a large amount of ozone utilisation in the treatment makes it an expensive process, and hence a less suitable option for pre-treatment at industrial scale (Kumar et al., 2009). Not much work on ozonolysis treatment of OPB is reported in the literature. Wan Omar and Amin (2016) studied the optimisation of lignin degradation and total reducing sugar recovery from OPF by ozonolysis pre-treatment by manipulating several operating conditions such as OPF particle size, moisture content, reaction time, ozone flow rate as well as their interaction by employing a response surface methodology. The optimum lignin degradation and total reducing sugar recovery were achieved at $84.7 \%$ and $99.9 \%$, respectively; with the levulinic acid production from the pre-treated OPF was comparable to that of commercial cellulose.

\section{Hydrothermal Pre-treatment}

A new emerging green technology known as hydrothermal treatments, commonly defined as reactions occurring under the conditions of high temperature and high pressure in aqueous solutions in a closed system (Rabemanolontsoa and Saka, 2016). The hydrothermal pre-treatment is widely applied on various lignocellulosic biomass to enhance their enzymatic digestibility as most of the hemicelluloses and partial lignin can be removed before the cellulose degrades under hydrothermal condition (Sun et al., 2016). The process temperatures are usually ranging from $160^{\circ} \mathrm{C}$ to $240^{\circ} \mathrm{C}$ as the cellulose degradation normally occurs at a temperature higher than $240^{\circ} \mathrm{C}$ (Cao et al., 2014; Sun et al., 2014). The system only uses water and the hydronium ion from water ionisation acts as a catalyst in the reaction medium (Möller et al., 2011; Sabiha-Hanim et al., 2011). Due to that reason, this method, is recognised as one of the most promising and environmental-friendly biomass pre-treatment methods available to make the lignocellulosic biomass susceptible to a subsequent process for fermentable sugars production. The hydrothermal pre-treatment is categorised into the steam explosion, liquid hot water or also referred to as hot compressed water as well as supercritical/ subcritical water depending on the conditions of temperature and pressure involved (Kumar and Sharma, 2017; Rabemanolontsoa and Saka, 2016).

Zakaria et al. (2015a) studied the effect of varying temperature $\left(170^{\circ} \mathrm{C}\right.$ to $\left.250^{\circ} \mathrm{C}\right)$ and time $(10$ to $20 \mathrm{~min}$ ) during hydrothermal pre-treatment in a batch tube reactor system on the glucose production from OPEFB and OPF fibre. Partial removal of hemicellulose and migration of lignin of treated samples resulting to expansion of the surface area and creation of pores for easy access to enzymes during enzymatic hydrolysis, thus enhancing the yield of glucose at $87.9 \%$ conversion from OPF fibre and $100 \%$ conversion from OPEFB. In another study also carried out by Zakaria et al. (2014b), they reported that a combined pre-treatment using hydrothermal and ball milling on OPMF in the tube reactor could improve hemicellulose removal and delignification as well as reduction in the cellulose particle size and its crystallinity. The highest yield of xylose and glucose obtained in the enzymatic hydrolysis on the treated sample were recorded at $63.2 \%$ and $97.3 \%$, respectively, which is the highest conversion from OPMF ever reported. Two different hydrothermal pre-treatments, namely SHS and HCW with a combination of wet disk milling (WDM) on OPMF were developed by Zakaria et al. (2015b). It was reported that the combination of HCW and WDM offered shorter milling cycles and lower power consumption with more than $98 \%$ of glucose yield. This eco-friendly combined pre-treatment is using hydrothermal and WDM to enhance the enzymatic efficiency of OPMF and claimed as the first to be reported. In an effort to overcome the difficulty of OPEFB degradation in a short period-time, hydrothermal pre-treatment has been developed under different reaction temperature $\left(100^{\circ} \mathrm{C}-250^{\circ} \mathrm{C}\right)$, reaction time (10-40 $\mathrm{min})$, solid to solvent ratio (1:10 - 1:20 w/v) and particle size (0.15-1.00 mm). The highest yield of soluble sugars at $68.18 \mathrm{mg}$ glucose per gram of OPEFB was obtained at $178^{\circ} \mathrm{C}, 20 \mathrm{~min}$ reaction time, $1: 15 \mathrm{w} / \mathrm{v}$ of solid to solvent ration for $30 \mathrm{~mm}$ of particle size (Muhd Ali et al., 2016). A pretreatment of OPF using $\mathrm{HCW}$ to enhance glucose 
recovery in enzymatic hydrolysis as a feedstock for bioethanol production has been studied by Goh et al. (2010). An application of central composite rotatable design for the process optimisation found that the optimum yield of glucose $(92.78 \%)$ was recorded at temperature of $178^{\circ} \mathrm{C}, 11.1 \mathrm{~min}$ reaction time and a liquid-solid ratio of 9.6 in a 10 bar pressurised reactor. Limited or no chemicals usage and environment-friendly process are the main advantages of the hydrothermal pre-treatment method. Despite their green process, hydrothermal presents the drawback of being costly, since it consumes high energy and water. The formation of toxic compounds to microorganisms and enzymes which impact the subsequent fermentation process is also a disadvantage associated with the hydrothermal pre-treatment (Sun et al., 2014; Brodeur et al., 2011).

\section{Summary of Lignocellulosic Oil Palm Biomass Pretreatments}

The main goal of numerous pre-treatment strategies that have been developed for OPB is to enhance the reactivity of cellulose and to increase the yield of fermentable sugars. The advantages and disadvantages of different pre-treatment methods are listed in Table 2.

TABLE 2. ADVANTAGES AND DISADVANTAGES OF DIFFERENT PRE-TREATMENT METHODS ON OIL PALM BIOMASS (OPB) LIGNOCELLULOSE

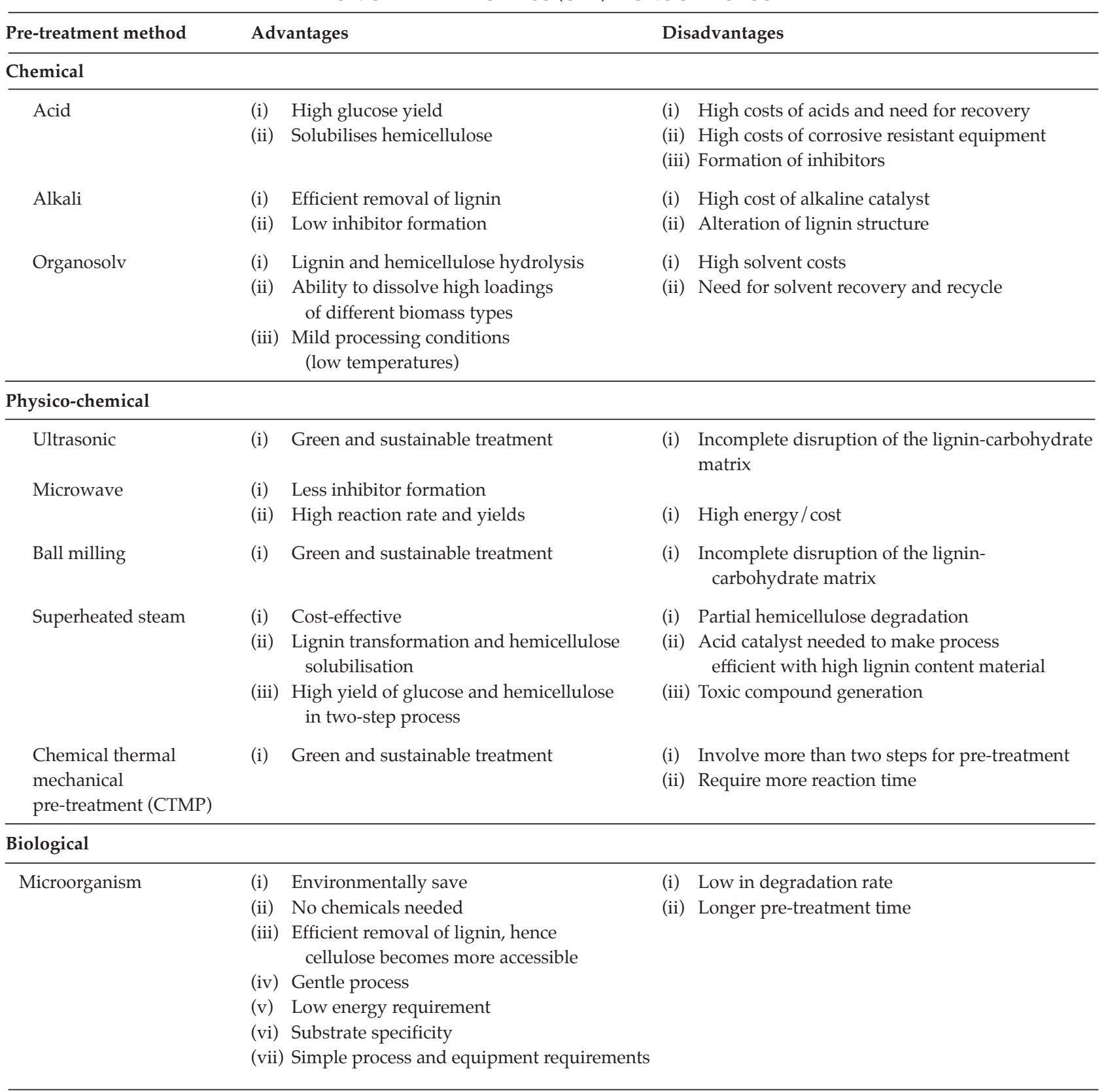


TABLE 2. ADVANTAGES AND DISADVANTAGES OF DIFFERENT PRE-TREATMENT METHODS ON OIL PALM BIOMASS (OPB) LIGNOCELLULOSE (continued)

\begin{tabular}{|c|c|c|c|c|}
\hline \multirow{2}{*}{$\begin{array}{l}\text { Pre-treatment method } \\
\text { Enzyme }\end{array}$} & \multicolumn{2}{|c|}{ Advantages } & \multicolumn{2}{|c|}{ Disadvantages } \\
\hline & (i) & $\begin{array}{l}\text { Mild processing conditions } \\
\text { (low temperature) }\end{array}$ & (i) & Longer treatment time \\
\hline & (ii) & Low energy requirement & (ii) & Low in hydrolysis rate \\
\hline & (iii) & Environmental-friendly & (iii) & Expensive process due to the high \\
\hline & (iv) & Efficient in lignin degradation & & cost of enzyme used \\
\hline & (v) & Specifically substrate targeted/higher selectiv & vity & \\
\hline \multicolumn{5}{|l|}{ Green } \\
\hline \multirow[t]{5}{*}{ Ionic liquid } & (i) & Green solvent - no harmful to environment & (i) & High cost of solvent \\
\hline & (ii) & Less amount of solvent needed & & \\
\hline & (iii) & Recyclable & & \\
\hline & (iv) & Low viscosity, non-volatility, non-flammability & & \\
\hline & (v) & Shorter processing time & & \\
\hline \multirow[t]{5}{*}{ Ozonolysis } & (i) & Eliminates the use of hazardous chemicals & (i) & Require large amount of ozone \\
\hline & (ii) & Efficient in lignin removal & (ii) & Expensive process \\
\hline & (iii) & $\begin{array}{l}\text { No formation of toxic residues and } \\
\text { toxic inhibitors }\end{array}$ & & \\
\hline & (iv) & $\begin{array}{l}\text { Operation at ambient temperature } \\
\text { and pressure }\end{array}$ & & \\
\hline & $(\mathrm{v})$ & Cellulose becomes more accessible & & \\
\hline \multirow[t]{4}{*}{ Hydrothermal } & (i) & Cost-effective process & (i) & Partial hemicellulose degradation \\
\hline & (ii) & Environmentally benign & (ii) & $\begin{array}{l}\text { Production of inhibitory compounds } \\
\text { to microorganisms and enzyme }\end{array}$ \\
\hline & (iii) & $\begin{array}{l}\text { Non-toxic, non-flammable, } \\
\text { non-carcinogenic, non-mutagenic } \\
\text { and thermodynamically stable }\end{array}$ & (iii) & High water input \\
\hline & (iv) & Increase cellulose accessible area & & \\
\hline
\end{tabular}

\section{CONCLUSION}

Lignocellulose has a highly crystalline and recalcitrant structure, as well as the presence of lignin in the OPB make the hydrolysis of cellulose and hemicellulose extremely difficult. Hence, various pre-treatment techniques for delignification of OPB have been developed. Common observed outcomes of pre-treatments include the decrease of lignin content, increase of surface area and the decrease of crystallinity of the biomass; all of which result in enhancing all of the subsequent processes (enzymatic saccharification and fermentation). This review focuses on chemical, physical, biological and their combination pre-treatment processes along with their advantages and disadvantages, and it will help the researchers in planning, selecting and developing the pre-treatment process for successful OPB conversion. This review also emphasises on the use of OPB as renewable and sustainable source of material for the production of value-added products, such as lignocellulosic chemicals, thus generating additional revenue for the country. This would diversify the utilisation of $\mathrm{OPB}$, which is normally used for biofertiliser and solid biofuel.

\section{ACKNOWLEDGEMENT}

The authors wish to thank the Director-General of MPOB for permission to publish this article. They also wish to thank the Deputy Director-General (Research \& Development) and Head of Biomass Technology Unit, MPOB for their support.

\section{REFERENCES}

ABDUL KHALIL, H P S; SITI ALWANI, $M$ and MOHD OMAR, A K (2006). Chemical composition, anatomy, lignin distribution, and cell wall structure of Malaysian plant fibres. Bioresources, 1(2): 220-232.

ABDUL KHALIL, H P S; SITI ALWANI, M; RIDZUAN, R; KAMARUDIN, $\mathrm{K}$ and KHAIRUL, A (2008). Chemical composition, morphology characteristics, and cell wall structure of Malaysian oil palm fibres. Polm. Plast. Technol. Eng., 47: 273-280.

ABDUL KHALIL, H P S and ROZMAN, H D (2004). Gentian dan Lignoselulosik. Universiti Sains Malaysia, Pulau Pinang, Malaysia. 
AHAMAD NORDIN, N I A; ARIFFIN, H; ANDOU, Y; HASSAN, M A; SHIRAI, Y; NISHIDA, H; WAN YUNUS, W M Z; KARUPPUCHAMY, $S$ and IBRAHIM, N A (2013). Modification of oil palm mesocarp fiber characteristics using superheated steam treatment. Molecules, 18: 9132-9146.

ALEKHINA, M S; MIKKONEN, K; ALEN, R; TENKANEN, M; and SIXTA, H (2014). Carboxymethylation of alkali extracted xylan for preparation of bio-based packaging films. Carbohydrate Polymers, 100: 89-96.

ALRIOLS, M.G; TEJADO, A; BLANCO, M; MONDRAGON, I and LABIDI, J (2009). Agricultural palm oil tree residues as raw material for cellulose, lignin and hemicelluloses production by ethylene glycol pulping process. Chemical Engineering J., 148(1): 106-114.

AMIN, N A S; YA'AINI, N; MISSON, M; HARON, $\mathrm{R}$ and MOHAMED, M (2010). Enzyme pretreated empty palm fruit bunch for biofuel production. $J$. Applied Sciences, 10(12): 1181-1186.

AMIRKHANI, H; YUNUS, R; RASHID, U; SALLEH, S F; DAYANG RADHIAH, A B and SYAM, S (2015). Low-temperature dilute acid hydrolysis of oil palm frond. Chemical Engineering Communications, 202: $1235-1244$.

ARATO, C; PYE, E K and GJENNESTAD, G (2005). The lignol approach to biorefining of woody biomass to produce ethanol and chemicals. Applied Biochemistry and Biotechnology, 123: 871-882.

ARIFFIN, H; HASSAN, M A; UMI KALSOM, M S; ABDULLAH, N and SHIRAI, Y (2008). Effect of physical, chemical and thermal pretreatments on the enzymatic hydrolysis of oil palm empty fruit bunch (OPEFB). J. Trop. Agric. and Fd. Sc., 36(2): 1-10.

ASAKURA, Y; NISHIDA, T; MATSUOKA, T and KODA, S (2008). Effects of ultrasonic frequency and liquid height on sonochemical efficiency of large-scale sonochemical reactors. Ultrasonics Sonochemistry, 15: 244-250.

ASTIMAR, A A; ANIS, M; KAMARUDIN, H; RIDZUAN, R; ROSNAH, M and WANHASAMUDIN, W H (2011). Chapter 28: Development in oil palm biomass utilisation. Further Advances in Oil Palm Research (2000-2010) (Mohd Basri, W; Choo, Y M and Chan, K W eds.).Vol. 2. MPOB, Bangi. p. 896-929.

ASTIMAR, A A; HUSIN, M and ANIS, M (2002). Preparation of cellulose from oil palm empty fruit bunches via ethanol digestion: effect of acid and alkali catalyst. J. Oil Palm Res. Vol. 14: 9-14.
BAHRIN, E K; BAHARUDDIN, A S; IBRAHIM, M F; RAZAK, M N A; SULAIMAN, A; ABD-AZIZ, S; HASSAN, M A; SHIRAI, Y and NISHIDA, H (2012). Physicochemical property changes and enzymatic hydrolysis enhancement of oil palm empty fruit bunches treated with superheated steam. Bioresource, 7(2): 1784-1801.

BALAT, M (2011). Production of bioethanol from lignocellulosic materials via the biochemical pathway: a review. Energy Conversion and Management, 52(2): 858-875.

BALI, G; MENG, X; DENEFF, J I; SUN, Q and RAGAUSKAS, A J (2015). The effect of alkaline pretreatment methods on cellulose structure and accessibility. ChemSustChem, 8(2): 275-279.

BANERJEE, G; CAR, S; LIU, T; WILLIAMS, D L; MEZA, S L; WALTON, J D and HODGE D B (2012). Scale-up and integration of alkaline hydrogen peroxide pretreatment, enzymatic hydrolysis, and ethanolic fermentation. Biotechnology and Bioengineering, 109: 922-931.

BEN, G D and MIRON, J (1981). The effect of combined chemical and enzyme treatment on the saccharification and in vitro digestion rate of wheat straw. Biotechnol. Bioeng., 23: 823-831.

BHAT, I U H; ABDULLAH, C K; ABDUL KHALIL, H P S; IBRAHIM, M H and NURUL FAZITA, M R (2011). Hybridized biocomposites from agro-wastes: mechanical, physical and thermal characterization. J. Polymer and the Environment, 19(1): 49-58.

BONO, A; YING, P H; YAN F Y; MUEI, C L; SARBATLY, R and KRISHNAIAH, D (2009). Synthesis and characterization of carboxymethyl cellulose from palm kernel cake. Advances in Natural and Applied Sciences, 3(1): 5-11.

BRODEUR, G; YAU, E; BADAL, K; COLLIER, J; RAMACHANDRAN, KB and RAMAKRISHNAN, $S$ (2011). Chemical and physicochemical pretreatment of lignocellulosic biomass: a review. Enzyme Research, 2011: 1-17.

CAO, X F; PENG, X W; SUN, S N; ZHONG, L X and SUN, R C (2014). Hydrothermal conversion of bamboo: identification and distribution of the components in solid residue, water-soluble and acetone-soluble fractions. J. Agric. Food Chem., 62: 12360-12365.

CHEN, C; BOLDOR, D; AITA, G and WALKER, $M$ (2012). Ethanol production from sorghum by microwave-assisted dilute ammonia pretreatment. J. Bioresource Technology, 110: 190-197. 
CHEW, T L and BHATIA, S (2008). Catalytic processes towards the production of biofuels in a palm oil and oil palm biomass-based biorefinery. Bioresource Technology, 99 (17): 7911-7922.

CHING, Y C and NG, TS (2014). Effect of preparation conditions on cellulose from oil palm empty fruit bunch fiber. Bioresources, 9(4): 6373-6385.

DAVIES, S M; LINFORTH, R S; WILKINSON, S J; SMART, K A and COOK, D J (2011). Rapid analysis of formic acid, acetic acid, and furfural in pretreated wheat straw hydrolysates and ethanol in a bioethanol fermentation using atmospheric pressure chemical ionization mass spectrometry. Biotechnology for Biofuels, 4: 1-8.

ESTEGHLALIAN, A; HASHIMOTO, A G; FENSKE, $\mathrm{J} \mathrm{J}$ and PENNER, M H (1997). Modeling and optimization of the dilute-sulfuric acid pretreatment of corn stover, poplar and switchgrass. Bioresource Technology, 59(2-3): 129-136.

ETHAIB, S; OMAR, R; KAMAL, S M M and BIAK, D R A (2015). Microwave-assisted pretreatment of lignocellulosic biomass: a review. J. Engineering Science and Technology Special Issue on SOMCHE 2014 \& RSCE 2014 Conference: 97-109.

GOH, C S; LEE, K T and BHATIA, S (2010). Hot compressed water pretreatment of oil palm fronds to enhance glucose recovery for production of second generation bio-ethanol. Bioresour. Technol., 101: 7362-7367.

GOH, C S; TAN, H T; LEE, K T and BROSSE, N (2011). Evaluation and optimization of organosolv pretreatment using combined severity factors and response surface methodology. Biomass Bioenergy, 35 (9): 4025-4033.

GUANBEN, D; WANG, S and CAI, Z (2005). Microwave drying of wood strands. Drying Technology, 23: 1-16.

HAMISAN, A F; ABD-AZIZ, S; KAMARUDDIN, K; MD SHAH, U K; SHAHAB, N and HASSAN, M A (2009). Delignification of oil palm empty fruit bunch using chemical and microbial pretreatment methods. International J. Agricultural Research, 4(8): 250-256.

HASIBUAN, R and WAN DAUD, W R (2009). Quality changes of superheated steam - dried fibers from oil palm empty fruit bunches. Dry. Technol., 27: 194-200.

HATAKKA, A I (1983). Pretreatment of wheat straw by white-rot fungi for enzymatic saccharification of cellulose. Eur. J. Appl. Microbiol. Biotechnol., 18: 350357.

HEINZE, T; SCHWIKAL, $\mathrm{K}$ and BARTHEL, $\mathrm{S}$ (2005). Ionic liquids as reaction medium in cellulose functionalization. Macromol. Biosci., 5: 520-525.

HENDRIKS, T W M and ZEEMAN, G (2009). Pretreatments to enhance the digestibility of lignocellulosic biomass. Bioresour. Technol., 100(1): 10-18.

ISROI; MILLATI, R; SYAMSIAH, S; NIKLASSON, $\mathrm{C}$; CAHYANTO, $\mathrm{M} \mathrm{N}$; LUNDQUIST, $\mathrm{K}$ and TAHERZADEH, M J (2011). Biological pretreatment of lignocelluloses with white-rot fungi and its applications: a review. Bioresources, 6: 5224-5259.

ISROI; MOFOLUWAKE, M I; RIA, M; SITI, S; MUHAMMAD, NC; CLAES, $\mathrm{N}$ and MOHAMMAD, $\mathrm{J} T$ (2012). Structural changes of oil palm empty fruit bunch (OPEFB) after fungal and phosphoric acid pretreatment. Molecules, 17: 14995-15012.

KIM, J S; LEE, Y Y and KIM, T H (2016). A review on alkaline pretreatment technology for bioconversion of lignocellulosic biomass. Bioresour. Technol., 199: $42-48$.

KIM, T H; GUPTA, R and LEE, Y Y (2009). Pretreatment of biomass by aqueous ammonia for bioethanol production. Biofuels: Methods and Protocols, 581: 79-91.

KIRK, T K and CHANG, H M (1981). Potential applications of bio-ligninolytic systems. Enzyme Microb. Technol., 3: 189-196.

KIRKALDY, J L R and SUSANTO, J B (1976). Possible utilisation of by-products from oil industry. The Planter, 52: 118.

KOMOLWANICH, T; TATIJARERN, P; PRASERTWASU, S; KHUMSUPAN, D; CHAISUWAN, T; LUENGNARUEMITCHAI, A and WONGKASEMJIT, S (2014). Comparative potentiality of Kans grass (Saccharum spontaneum) and Giant reed (Arundo donax) as lignocellulosic feedstocks for the release of monomeric sugars by microwave/chemical pretreatment. J. Cellulose, 21(3): 1327-1340.

KOOTSTRA, A M J; BEEFTINK, H H; SCOTT, E L and SANDERS, J P M (2009). Comparison of dilute mineral and organic acid pretreatment for enzymatic hydrolysis of wheat straw. Biochemical Engineering J., 46: 126-131.

KRISTIANI, A; ABIMANYU, H; SETIAWAN, A H; SUDIYARMANTO and AULIA, F (2013). Effect 
of pretreatment process by using diluted acid to characteristic of oil palm's frond. Energy Procedia, 32: 183-189.

KUMAR, A K and SHARMA, S (2017). Recent updates on different methods of pretreatment of lignocellulosic feedstocks: a review. Bioresources and Bioprocessing, 4(1): 7-25.

KUMAR, D and MURTHY, G S (2011). Impact of pretreatment and downstream processing technologies on economics and energy in cellulosic ethanol production. Biotechnology for Biofuels, 4(27): $1-19$.

KUMAR, P; BARRET, D M; DELWICHE, M J and STROEVE, P (2009). Methods for pretreatment of lignocellulosic biomass for efficient hydrolysis and biofuel production. Ind. Eng. Chem. Res., 48: 37133729 .

KURAKAKE, M; IDE, N and KOMAKI, T (2007). Biological pretreatment with two bacterial strains for enzymatic hydrolysis of office paper. Curr. Microbial, 54: 424-428.

LAW, K N; DAUD, W R W and GHAZALI, A (2007). Morphological and chemical nature of fiber strands of oil palm empty-fruit-bunch (OPEFB). Bioresources, 2(3): 351-362.

LAW, K N and JIANG, X (2001). Comparative papermaking properties of oil-palm empty fruit bunch. TAPPI J., 84(1): 95.

LEIKER, M and ADAMSKA, M A (2004). Energy efficiency and drying rates during vacuum microwave drying of wood. Holz als Roh - und Werkstoff, 62(3): 203-208.

LÜ, J and ZHOU, P (2011). Optimisation of microwave-assisted $\mathrm{FeCl} 3$ pretreatment conditions of rice straw and utilisation of Trichoderma viride and Bacillus pumilus for production of reducing sugars. J. Bioresource Technology, 102(13): 6966-6971.

MARTINEZ, A T; CAMARERO, S; GUILLÊN, G; GUTIÊRREZ, A; MUÑOZ, C; VARELA, E; MARTINEZ, M J; BARRASA, J; RUEL, $\mathrm{K}$ and PELAYO, J (1994). Progress in biopulping on non-woody materials: chemicals, enzymatic and ultrastructural aspects of wheat straw delignification with ligninolytic fungi from the genus Pleurotus. FEMS Microbiol. Rev., 13: 265-273.

MARZIALETTI, T; MILLER, S J; JONES, C W and AGRAWAL, P K (2011). Switchgrass pretreatment and hydrolysis using low concentrations of formic acid. J. Chemical Technology E Biotechnology, 86(5): 706-713.
MEDINA, J D C; WOICIECHOWSK, A; FILHO, A Z; NOSEDA, M D; KAUR, B S and SOCCOL, C $R$ (2015). Lignin preparation from oil palm empty fruit bunches by sequential acid/alkaline treatment - a biorefinery approach. Bioresource Technology, 194: 172-178.

MOHD BASYARUDDIN, A R; ZATI, I I; DZULKEFLY, K A; ASTIMAR, A A; MAHIRAN, B and ABU BAKAR, $S$ (2012). Swelling and dissolution of oil palm biomass in ionic liquids. J. Oil Palm Res. Vol. 24: 1267-1276.

MOHD NASIR, M A and SALEH, S H (2016). Characterization of hemicelluloses from oil palm empty fruit bunches obtained by alkaline extraction and ethanol precipitation. Malaysian J. Analytical Sciences, 20(4): 849-855.

MOHD SUKRI, S S; RAHMAN,R A; ILLIAS, R M and YAAKOB, $\mathrm{H}$ (2014). Optimization of alkaline pretreatment conditions of oil palm fronds in improving the lignocelluloses contents for reducing sugar production. Romanian Biotechnological Letters, 19(1): 9006-9018.

MOHTAR, S S; TENGKU MALIM BUSU, T N Z; MD NOOR, A M; SHAARI, N; YUSOFF, N A; BUSTAM@ KHALIL, M A; ABDUL MUTALIB, M I and MAT, $\mathrm{H} B$ (2015). Extraction and characterization of lignin from oil palm biomass via ionic liquid dissolution and non-toxic aluminium potassium sulfate dodecahydrate precipitation processes. Bioresour. Technol., 192: 212-218.

MOISER, N; WYMAN, C; DALE, B; ELANDER, R; LEE, Y Y; HOLTZAPPLE, M and LADISH, M (2005). Features of promising technologies for pretreatment of lignocellulosic biomass. Bioresour. Technol., 96: 673-686.

MÖLLER, M; NILGES, P; HARNISCH, F and SCHRÖDER, U (2011). Subcritical water as reaction environment: fundamentals of hydrothermal biomass transformation. ChemSustChem., 4: 566-579.

MORA-PALE, M; MELI, L; DOHERTY, T V, LINHARDT, R J and DORDICK, J S (2011). Room temperature ionic liquids as emerging solvents for the pretreatment of lignocellulosic biomass. Bioethanol Bioeng., 108(6): 1229-1245.

MPOB (2016). Malaysian Oil Palm Statistics. MPOB, Bangi. http:/ / bepi.mpob.gov.my/index.php/en/, accessed on 29 August 2017.

MUHD ALI, M D; TAMUNAIDU, P; NOR ASLAN, A K H; MORAD, N A; SUGIURA, N; GOTO, M and ZHANG, Z (2016). Hydrothermal pre-treatment of 
oil palm empty fruit bunch into fermentable sugars. International Conference on Chemical Engineering and Bioprocess Engineering IOP, Conf. Series: Earth and Environmental Science 36 (2016). DOI:10.1088/1755$1315 / 36 / 1 / 012042$

NAZIR, M S; WAHJOEDI, B A; YUSSOF, A W and ABDULLAH, M A (2013). Eco-friendly extraction and characterization of cellulose from oil palm empty fruit bunches. BioResources, 8(2): 2161-2172.

NAZIR, M S; WAHJOEDI, B A; YUSSOF, A W and ABDULLAH, M A (2012). Green extraction and characterization of cellulose fibers from oil palm empty fruit bunch. $2^{\text {nd }}$ International Conference on Process Engineering and Advanced Materials (ICPEAM2012) under World Engineering, Science \& Technology Congress (ESTCON2012). Kuala Lumpur, Malaysia.

NAZLEE, F G; QADLY, A P; KHAIRILANUAR, M $\mathrm{H}$ and NURUL, A M (2017). Enzymatic hydrolysis of oil palm empty fruit bunch using membrane reactor. Chemical Engineering Transactions, 56: 1543-1548.

NEELY, WC (1984). Factors affecting the pretreatment of biomass with gaseous ozone. Biotechnol. Bioeng., 26: 59-65.

NGUYEN, Q A; TUCKER, M P; KELLER, F A and EDDY, FP (2000). Two-stage dilute-acid pretreatment of softwoods. Applied Biochemistry and Biotechnology, Part A, 84-86: 561-576.

NIK MAHMUD, N A; BAHARUDDIN, A S; BAHRIN, E K; SULAIMAN, A; NAIM, M N and ZAKARIA, R (2013). Enzymatic saccharification of oil palm mesocarp fiber (OPMF) treated with superheated steam. Bioresources, 8: 1320-1331.

NOMANBHAY, $\mathrm{M}$ S; HUSSAIN, $\mathrm{R}$ and PALANISAMY, K (2013). Microwave-assisted alkaline pretreatment and microwave assisted enzymatic saccharification of oil palm empty fruit bunch fiber for enhanced fermentable sugar yield. J. Sustainable Bioenergy Systems, 3(1): 7-17.

NOORSHAMSIANA, A W; ASTIMAR, A A; NOR FAIZAH, J and MOHAMADIAH, B (2015). Enzymatic production of xylo-oligosaccharides from fibres of empty fruit bunch. MPOB Information Series No. 701. Palmoilis.mpob.gov.my/ publications/ TOT/TT-572.pdf.

NORZITA N and LANI, N S (2014). Extraction and characterization of cellulose from empty fruit bunch (EFB) fiber. J. Teknologi, 68(5): 35-39.

PARISA, A; ABDUL KHALIL, H P S; BABAK, S; AHMAD ZUHAIRI, A and ISSAM, A M (2010).
Optimization of bioresource material from oil palm trunk core drying using microwave radiation; a response surface methodology application. Bioresour. Technol., 101: 8396-8401.

PRIOR, B A and DAY, D F (2008). Hydrolysis of ammonia-pretreated sugarcane bagasse with cellulase, beta-glucosidase, and hemicellulase preparations. Applied Biochemistry and Biotechnology, 146: 151-64.

PYE, E K and LORA, J H (1991). The AlcellTM process: a proven alternative to kraft pulping. TAPPI J., 74: 113-117.

QUESADA, J; RUBIO, M and GOMEZ, D (1999). Ozonation of lignin-rich solid fractions from corn stalks. J. Wood Chem. Technol., 19: 115-137.

RABEMANOLONTSOA, H and SAKA, S (2016). Various pretreatment of lignocellulosics. Bioresource Technology, 199: 83-91.

RAVEENDRAN, K; GANESH, A and KHILAR, K C (1995). Influence of mineral matter on biomass pyrolysis characteristics. Fuel, 74 (12): 1812-1822.

RAY, M J; LEAK, D J; SPANU, P D and MURPHY, R J (2010). Brown rot fungal early stage decay mechanism as a biological pretreatment for softwood biomass in biofuel production. Biomass Bioenergy, 34: 1257-1262.

ROBIAH, Y; SHANTI FARIDAH, S; NURHAFIZAH, A and DYG RADIAH, A B (2010). Effect of ultrasonic pre-treatment on low-temperature acid hydrolysis of oil palm empty fruit bunch. Bioresour. Technol., 101: 9792-9796.

ROSMAN, S; SAKINAH, M A; RUZITAH, M S and MOHAMMED IQBAL, S (2013). Polylactic acid/ empty fruit bunch fiber biocomposite: influence of alkaline and silane treatment on the mechanical properties. International J. Bioscience, Biochemistry and Bioinformatics, 3(1): 59-61.

ROSNAH, M S, ASTIMAR, A A; WAN HASAMUDIN, W H and AB GAPOR, M T (2009). Solid-state characteristics of microcrystalline cellulose from oil palm empty fruit bunch fibre. J. Oil Palm Res. Vol. 21: 272-277.

ROSNAH, M S; WAN HASAMUDIN, W H; AB GAPOR, M T and KAMARUDIN, H (2006). Thermal properties of oil palm fibre, cellulose and its derivatives. J. Oil Palm Res. Vol. 18: 272-276.

RUGAYAH, A F; ASTIMAR, A A and NORZITA, $N$ (2014). Preparation and characterizations of 
activated carbon from palm kernel shell by physical activation with steam. J. Oil Palm Res. Vol. 26(3): 251264.

SABIHA-HANIM, S; MOHD NOOR, $\mathrm{M}$ A and ROSMA, A (2011). Effect of autohydrolysis and enzymatic treatment on oil palm (Elaeis guineensis Jacq.) frond fibres for xylose and xylooligosaccharides production. Bioresour. Technol., 102: $1234-1239$

SAHA, B C; ITEN, L B; COTTA, M A and WU, Y V (2005). Dilute acid pretreatment, enzymatic saccharification, and fermentation of rice hulls to ethanol. Biotechnology Progress, 21(3): 816-822.

SAKA, S; MUNUSAMY, M V; SHIBATA, M; TONO, $\mathrm{Y}$ and MIYAFIJU, H (2008). Chemical constituents of the different anatomical parts of the oil palm (Elaeis guineensis) for their sustainable utilization. Proc. of the JSPS-VCC Group Seminar 2008, Natural Resources $\mathcal{E}$ Energy Environment. 24-25 November 2008, Kyoto University, Kyoto, Japan. p. 19-34.

SASSNER, P; MARTENSSON, C G; GALBE, $M$ and ZACCHI, G (2008). Steam pretreatment of $\mathrm{H}_{2} \mathrm{SO}_{4}$ impregnated salix for the production of bioethanol. Bioresour. Technol., 99(1): 137-145.

SCHWARTZE, J P and BROCKER, S A (2002). Theoretical explanation for the inversion temperature. Chem. Eng. J., 86: 61-67.

SHARMA, R; PALLED, V; SHARMA-SHIVAPPA, R $\mathrm{R}$ and OSBORNE, J (2013). Potential of potassium hydroxide pretreatment of switchgrass for fermentable sugar production. Applied Biochemistry and Biotechnology, 169: 761-772.

SHERMAN, S R; GODELL, J J; MILLIKEN, C E; MORRIS, J A and GORENSEK, M B (2012). A new process developed for separation of lignin from ammonium hydroxide pretreatment solutions. Environmental Progress \& Sustainable Energy, 31: 130138.

SHIBATA, M; VARMAN, M; TONO, Y; MIYAFUJI, $\mathrm{H}$ and SAKA, $\mathrm{S}$ (2008). Characterization in chemical composition of the oil palm (Elaeis guineensis). J. Jpn. Inst. Energy, 8(5): 383-388.

SHINOJ, S R; VISVANATHAN, S; PANIGRAHI, S and KOCHUBABU, M (2011). Oil palm fiber (OPF) and its composites: a review. Industrial Crops and Products, 33(1): 7-22.

SIDEK, D A B; NORZITA, N and AMIN, N A S (2013). Optimization of lignin production from empty fruit bunch via liquefaction with ionic liquid. Bioresour. Technol., 135: 690-696.
SIERRA, R; GRANDA, C B and HOLTZAPPLE, M T (2009). Lime pretreatment. Biofuels: Methods and Protocols. p. 115-124

SILVERSTEIN, R A; CHEN, $\mathrm{Y}$ and SHARMASHIVAPPA, R R (2007). A comparison of chemical pretreatment methods for improving saccharification of cotton stalks. Bioresour. Technol., 98(16): 3000-3011.

SREEKALA, M S; GEORGE, J; KUMARAN, M G and THOMAS, $S$ (2001). Water-sorption kinetics in oil palm fibers. J. Polymer Science, Part B: Polymer Physics, 39(11): 1215-1223.

SUN, S; CAO, X F; SUN, S L; XU, F; SONG, X L; SUN, R C and JONES, G L (2014). Improving the enzymatic hydrolysis of therm0-mechanical fiber from Eucalyptus urophylla by a combination of hydrothermal pretreatment and alkali fractionation. Biotechnol. Biofuels, 7: 116-127.

SUN, S; SUN, S; CAO, X and SUN, R (2016). The role of pretreatment in improving the enzymatic hydrolysis of lignocellulosic materials. Bioresour. Technol., 199: 49-58.

SUN, Y and CHENG, J (2002). Hydrolysis of lignocellulosic materials for ethanol production: a review. Bioresour. Technol., 83(1): 1-11.

TAHERZADEH, M J and KARIMI, K (2008). Pretreatment of lignocellulosic wastes to improve ethanol and biogas production: a review. International J. Molecular Sciences, 9: 1621-1651.

TAN, H T; LEE, K T and MOHAMED, A R (2011). Pretreatment of lignocellulosic palm biomass using a solvent-ionic liquid [BMIM]Cl for glucose recovery: an optimization study using response surface methodology. Carbohydr. Polym., 83: 18621868.

TANIGUCHI, M; SUZUKI, H; WATANABE, D; SAKAI, K; HOSHINO, K and TANAKA, T (2005). Evaluation of pretreatment with Pleurotus ostreatus for enzymatic hydrolysis of rice straw. J. Biosci. Bioeng., 100: 637-643.

TOMA, M; VINATORU, M; PANIWNYK, L and MASON, T J (2007). Investigation of the effects of ultrasound on vegetal tissues during solvent extraction. Ultrasonics Sonochemistry, 8: 137-142.

TORGOVNIKOV, G and VINDEN, P (2002). Microwave method for increasing the permeability of wood and its applications. Advances in Microwave and Radio Frequency Processing (Willert-Porada, M ed.). Springer, Berlin, Heidelberg. p. 303-311. 
TRZCINSKI, A P and STUCKEY, D C (2015). Contribution of acetic acid to the hydrolysis of lignocellulosic biomass under abiotic conditions. Bioresour. Technol., 185: 441-444.

VATS, S; MAURYA, D P; SHAIMOON, M and NEGI, S (2013). Development of a microbial consortium for the production of blend enzymes for the hydrolysis of agricultural waste into sugars. J Sci Ind Res, 72: 585-590.

VERMAAS, H F (1995). Drying eucalypts for quality: material characteristics, pre-drying treatments, drying methods, schedules and optimization of drying quality. Suid-Afrikaance Bosboutydskrif, 174: 41-49.

VIDAL, P F and MOLINIER, J (1988). Ozonolysis of lignin - improvement of in vitro digestibility of polar sawdust. Biomass, 16: 1-17.

WAN ROSLI, W D; ZAINUDDIN, Z; LAW, K N and ASRO, R (2007). Pulp from oil palm fronds by chemical processes. Industrial Crops and Products, 25 : 89-94.

WANG, Z; KESHWANI, D R; REDDING, A P and CHENG, J J (2010). Sodium hydroxide pretreatment and enzymatic hydrolysis of coastal Bermuda grass. Bioresour. Technol., 101: 3583-3585.

WANITWATTANARUMLUG, B; LUENGNAR UEMITCHAI, A and WONGKASEMJIT, S (2012). Characterization of corn cobs from microwave and potassium hydroxide pretreatment. International J. Chemical, Molecular, Nuclear, Materials and Metallurgical Engineering, 6(4): 327-331.

WAN OMAR, W N N and AMIN, N A S (2016). Multi-response optimization of oil palm frond pretreatment by ozonolysis. Industrial Crops and Products, 85: 389-402.

YONGA, T L; MOHAMAD, $\mathrm{N}$ and MOHAMAD YUSOF, N N (2016). Furfural production from oil palm biomass using a biomass-derived supercritical ethanol solvent and formic acid catalyst. Procedia Engineering, 148: 392-400.

ZADRAŽIL, F and PUNIYA, A K (1995). Studies on the effect of particle size on solid-state fermentation of sugarcane bagasse into animal feed using whiterot fungi. Bioresour. Technol., 54: 85-87.

ZAKARIA, M R; HIRATA, S and HASSAN, M A (2015a). Hydrothermal pretreatment enhanced enzymatic hydrolysis and glucose production from oil palm biomass. Bioresour. Technol., 176: 142-148.
ZAKARIA, M R; NORRRAHIM M N F; HIRATA, $S$ and HASSAN, M A (2015b). Hydrothermal and wet milling pretreatment for high conversion of biosugars from oil palm mesocarp fiber. Bioresour. Technol., 181: 263-269.

ZAKARIA, M R; FUJIMOTO, S; HIRATA, S and HASSAN, M A (2014a). Ball milling pretreatment of oil palm biomass for enhancing enzymatic hydrolysis. Appl. Biochem. Biotechnol., 173(7): 17781789.

ZAKARIA, M R; HIRATA, S and HASSAN, M A (2014b). Combined pretreatment using alkaline hydrothermal and ball milling to enhance enzymatic hydrolysis of oil palm mesocarp fiber. Bioresour. Technol.: 236-243.

ZAWAWI, I; ASTIMAR, A A; RIDZUAN, R; KAMARUZAMAN, J; MANSUR, $\mathrm{A}$ and MOHD ARIFF, J (2015). Effect of treatment on the oil content and surface morphology of oil palm (Elaeis guineensis) empty fruit bunches (EFB) fibres. Wood Research, 60(1): 157-166.

ZHANG, L; AVRAMIDIS, S and HATZIKIRIAKOS, S G (1997). Moisture flow characteristics during radio frequency vacuum drying of thick lumber. Wood Science and Technology, 31(4): 265-277.

ZHANG, Y H P; DING, S Y and MIELENZ, J R (2007). Fractionating recalcitrant lignocellulose at modest reaction conditions. Biotechnology and Bioengineering, 97(2): 214-223.

ZHAO, X B; CHENG, K K and LIU, D H (2009). Organosolv pretreatment of lignocellulosic biomass for enzymatic hydrolysis. Applied Microbiology and Biotechnology, 82: 815-827.

ZHAO, Y; WANG, Y; ZHU, J Y; RAGAUSKAS, $A$ and DENG, $Y$ (2008). Enhanced enzymatic hydrolysis of spruce by alkaline pretreatment at low temperature. Biotechnology and Bioengineering, 99(6): 1320-1328.

ZHENG, Y; PAN, Z and ZHANG, R (2009). Overview of biomass pretreatment for cellulosic ethanol production. International J. Agricultural and Biological Engineering, 2: 51-68.

ZHU,S D; WU, Y X; CHEN, Q M; YU, Z N; WANG, C W; JIN, S W; DING, Y G and WU, G (2006). Dissolution of cellulose with ionic liquids and its application: a mini-review. Green Chemistry, 8: 325327. 